\title{
Conceptualizing the role of self-esteem in the burnout process
}

\author{
Dian Faqihdien Suzabar ${ }^{\mathrm{a}}$, Mochamad Soelton ${ }^{\mathrm{a}^{*}}$, Erna Sofriana Imaningsih ${ }^{\mathrm{b}}$, Inge Hutagalung ${ }^{\mathrm{c}}$ and Aman \\ Dwi Suherman ${ }^{\text {d }}$
}

\author{
${ }^{a}$ Management Department, Faculty of Economic and Business, Universitas Brawijaya, Indonesia \\ ${ }^{b}$ Management Department, Faculty of Economic and Business, Universitas Mercu Buana, Indonesia \\ ${ }^{c}$ Communication Department, Faculty of Communication Science, Universitas Mercu Buana, Indonesia \\ ${ }^{d}$ Student, Management Department, Faculty of Economic and Business, Universitas Mercu Buana, Indonesia
}

\section{H R O N I C L E}

\section{Article history:}

Received: April 29, 2020

Received in revised format:

April 302020

Accepted: May 30, 2020

Available online:

June 2, 2020

Keywords:

Workload

Demographic factor

Locus of control

Self esteem

Workstress

Burnout

\section{A B S T R A C T}

This study aims to examine and analyze the influence of Workload, Demographic Factors, Locus of Control, Self Esteem and Workstress on Burnout in the Senior Masinists. The research method used in this research is descriptive method. Questionnaires were distributed to 43 respondent employees of The Indonesia Railway Industry. The approach used in this research is a Variancebased Model or Structural Equation Model with a Smart-PLS analysis tool. The results show that the four variables namely Workload, Demography, Locus of Control and Work Stress had positive and significant effects on Burnout on Machinists while the Self-Esteem Variable did not have a significant effect on Burnout.

\section{Introduction}

The role of management of Human Resources (HR) is crucial for the realization of organizational goals, but how to lead people is a difficult task. In addition to being expected to be capable, skilled workers must also be willing and have the determination to work effectively and efficiently. Ability and skills will be less meaningful if not followed by work morale and employee discipline in realizing the goals (Suzabar et al., 2020). According to Soelton and Nugrahati (2018) human resource management is an ongoing procedure that aims to supply an organization or company with the right people to be placed in the right position and the position when the organization needs it especially in service companies, where there is always an interaction between HR and consumers, directly. The company must also anticipate any possibility of problems in the management of HR starting from the selection stage to the end, namely a more complex HR management process. The important role of HR in service companies must be differentiated for further management (Soelton \& Nugrahati, 2018; Suzabar et al., 2020). A service company, in general has the same goal which is to provide the best quality for the consumers' needs, success in maintaining quality, getting profit, developing the work and to achieve these objectives, the use of human resources is needed. With the very tight competition, it must be balanced with the development of human resources in improving the quality of work as a motivator so that employees can perform the service process quickly and precisely (Soelton et al., 2020). One factor that can cause negligence in service companies is due to the Burnout factor experienced by HR employees. Dyrbye and Shanafelt (2011) suggested Burnout as a development process in which an employee could be frustrated and emotionally changed to indirectly produce personal conflicts between employees when facing work pressure and then protect themselves by shrinking emotions in themselves. Some experts also define Burnout as physical, emotional, and psychological fatigue, 
which arises in physical fatigue and long-term fatigue, feeling helpless and undeveloped, and negative concepts and attitudes towards work, life, or others (Shafiezadeh, 2011). There are several studies associated with the understanding of burnout from several other experts regarding burnout as a result of prolonged stress at work which is characterized by emotional, depersonalization, and being satisfied with one's achievements (Soelton et al., 2018). In addition, Soelton and Atnani (2018) explained the risk of overwork regarding low employees, increased work, low work teams, and disobeying regulations to further influence organizational performance and strengthen employee centripetal. Based on the conclusions of some of these experts, it can be concluded that burnout is very dangerous for one's success because this problem arises in the long run and results in boredom for employees in working related to boredom. One product that is in great demand by the public today is the Electric Rail Train, which is often known as the KRL or Indonesian Commuter Train. Until now, the KRL trip schedule in JABODETABEK and Rangkas Bitung and Cikarang have amounted to approximately 938 (nine hundred thirty-eight) train travel schedules with passenger volumes reaching 1.1 million passengers per day (www.kai.id). Labor productivity is one of the things that need to be considered in order to support the success. Employee productivity can be judged from what employees do in their work. Productivity can also be a reflection of a high work ethic. The higher productivity of employees in the company, the higher of earnings and profits of the company. Thus, productivity can be represented by the income or profits to be earned individual labor. Labor productivity is affected by the consciousness of each individual (such as discipline, attitude and environment) level of education and training has been received as well as self-management capabilities (www.kai.id). But in fact, the productivity of a company is also influenced by several other factors. With that a company needs to pay attention to factors that affect the productivity so that productivity is increasing and not decreasing. Most companies have experienced a decline of productivity making it difficult to achieve organizational goals and one of these companies, namely The Indonesia Railway Industry. From the percentage yield productivity gains, in 2017 amounted to $91.60 \%$, but decreased in 2018 and 2019 with a percentage of $91.25 \%$ and $90.70 \%$, respectively. For 3 years, it has decreased and has not reached the predetermined targets.

\section{Lliterature review}

\subsection{Human Resource Management}

Human Resource Management according to Dessler (2013) is the process of obtaining, training, assessing, and giving compensation to employees as well as presenting themselves in employment relations, health and safety, and the concepts and techniques needed to move people or aspects personnel from management jobs.

\subsection{Burnout}

Burnout is a new phenomenon in the field of psychology. Understanding this concept existed more or less 50 years ago, but it was only in 1974 that the Burnout problem was the subject of study by psychologists. Burnout is a term that was first coined by Freudenberger in 1974, which is a representation of psychological stress syndrome which shows a negative response as a result of work pressure. Dimensions and Indicators of Burnout are as follows:

- Physical fatigue - Like insomnia, Headache attack, The lack of appetite, Individuals feel sick limbs.

- Emotional fatigue - Depression, irritability, Offended quickly

- Mental fatigue - Like being cynical about others, tends to harm yourself, work, or organization.

- Low self-esteem - As individuals never feel satisfied with the results of their work.

- Depersonalization - Like keeping individuals away from the social environment, apathy does not care about the environment and the people around it.

\subsection{Workload}

According to Soelton et al., (2019), Workload is defined as the amount of work activity that must be completed by a person or group at a certain time when the situation is normal. According to Tarwaka (2015), the following are the dimensions of workload size associated with performance:

- Time load - Too much time overtime, There is almost no free time

- Mental effort load - Very little mental effort is needed with mindfulness or very little concentration is needed., Enough mental effort is needed with awareness or enough concentration, it takes mental effort and a high concentration of very complex activities so that full attention is needed.

\subsection{Demographic Factor}

Therefore, demographics can be interpreted as writing or describing the population, especially regarding birth, marriage, death, and migration.

\subsection{Locus of Control}

Locus of control according to Rotter quoted from (Soelton et al., 2020; Suwarsi \& Budianti, 2009) is certain to contribute to the quality of performance in a person, namely the initial response as the basis for the response that will be done next. Locus of Control Dimension is divided into 2 (two): 
- Internal Locus of Control - The belief that success achieved is proportional to the effort they put in and they can largely control.

- External Locus Of Control - Individuals with External Locus of Control have confidence that their actions have little impact on their success/failure, and there is little they can do to change them.

\subsection{Self Esteem}

Coopersmith (1967) suggested that Self Esteem is a self-assessment carried out by individuals relating to themselves that reflects the attitude of acceptance and rejection and shows how far the individual believes that he is capable, important, successful, and valuable.

\subsection{Work stress}

Working stress is a feeling of stress experienced by employees in dealing with work. This work stress can be seen from symptoms, including unstable emotions, feeling uneasy, like to be alone, difficulty sleeping, excessive smoking, unable to relax, anxiety, tension, nervousness, increased blood pressure, and experiencing indigestion. Dimensions and Indicators according to Robbins and Judge (2014):

- Task Demands - Inadequate equipment, Equipment needed to work often does not work well, Excessive workload, Responsibility for the work of others

- Role demands - Unclear work responsibilities, Unable to complete ordinary day work, Organizational structure, that is, like the lack of personnel in one section

- The attitude of the leadership - Bosses do not give clear instructions, Information for completing work., The amount of work does not affect the results.

Conceptual framework

This model was made based on the review of the literature for this paper and is shown in Fig. 1.

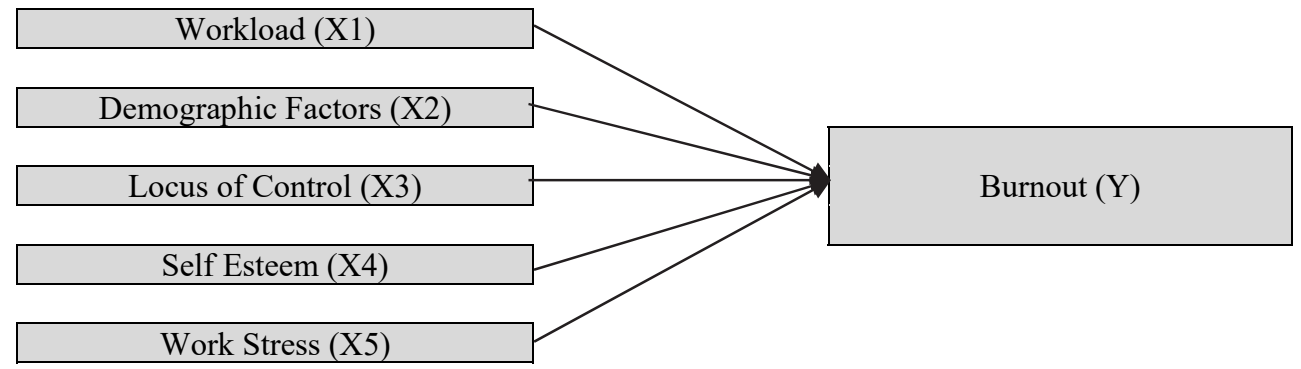

Fig. 1. Conceptual Framework

Regarding the previous, the following hypotheses are proposed:

$\mathrm{H}_{1}$ : Workload has a positive influence on Burnout.

$\mathrm{H}_{2}$ : Demographic Factors has a positive influence on Burnout.

$\mathrm{H}_{3}$ : Locus of Control has a positive influence on Burnout.

$\mathrm{H}_{4}$ : Self Esteem has a positive influence on Burnout.

$\mathrm{H}_{5}$ : Work Stress has a positive influence on Burnout.

\section{Methodology}

\subsection{Research Design}

In this study, the study design used is classified as causal research. Causal research design is useful to analyze the relationships between the variables with other variables. In this study, researchers interested in examining the independent variables are stress, psyches environment, self-efficacy to productivity as the dependent variable with Burnout as an intervening variable in The Indonesia Railway Industry.

\subsection{Data Collection Instrument}

The instrument used for data collection was a questionnaire submitted to the employees. Questionnaires were distributed to 43 respondent employees of The Indonesia Railway Industry. The population in this study is a machinist The Indonesia Railway Industry at Manggarai (PT. KCI, Manggarai Branch) totaling 398 employees consisting of 43. With determination of the samples used in this study using a type of saturated sample method. The sample in this study were 43 respondents with the status of employees of The Indonesia Railway Industry. Unit for the population of employees with a number of 43 employees, by providing questionnaires to employees or employees of The Indonesia Railway Industry. The analytical method used in this study is the Component or Variance Based Structural Equation Model in which the data processing using the program Partial Least Square (Smart-PLS) PLS 3.2.8 version. PLS (Partial Least Square) is the alternative models of covariance-based SEM. 


\section{Results and discussion}

\subsection{Validity and Test Reliability}

Table 1

Results of Convergent Validity Testing

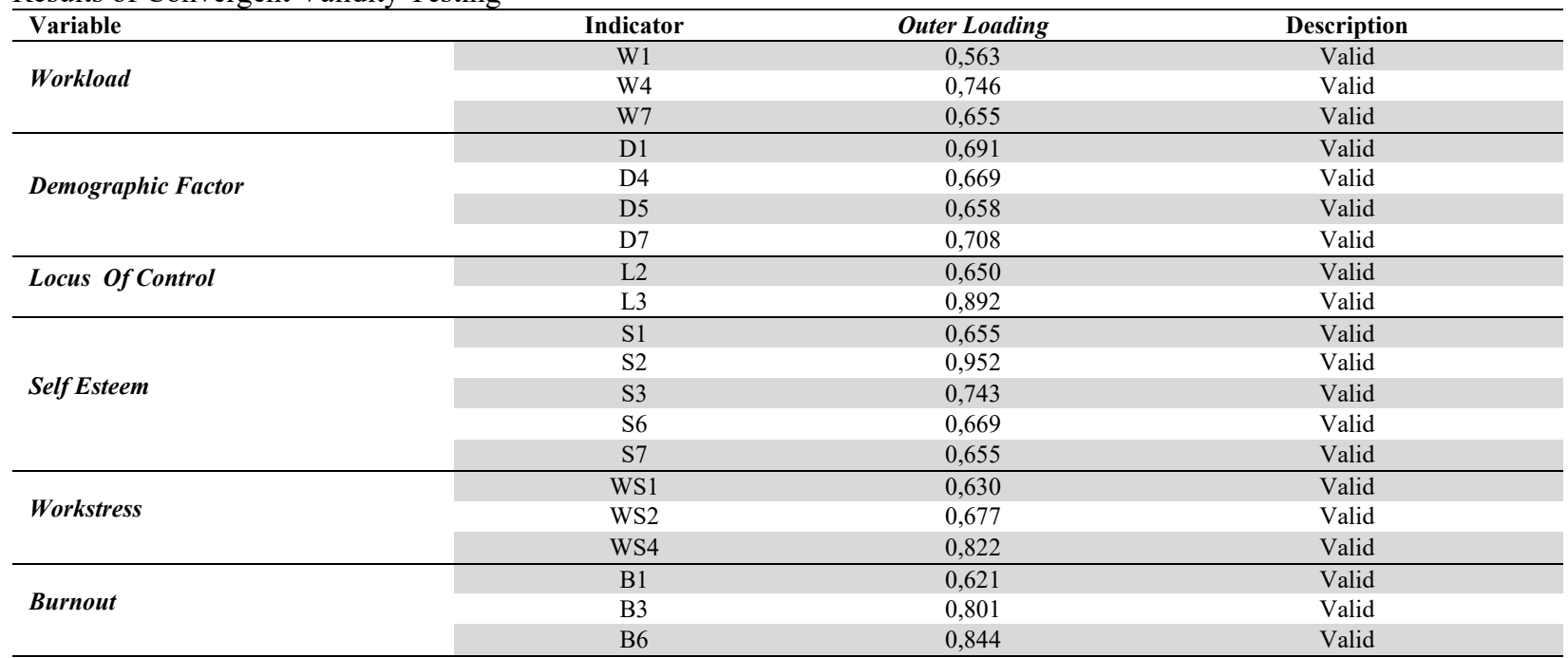

Source : Output PLS

The results of the modification of the convergent validity test in Tables and Figures can be seen that all indicators meet the convergent validity because they have loading factor values above 0.50 . In addition to the loading factor value to analyze the validity of research data one can use the Average Variance Extracted (AVE) value. Here is a table of validity test values using the value of AVE (Average Variance Extracted).

Table 2

Composite Reliability and Cronbach Alpha Test Results

\begin{tabular}{|c|c|c|c|}
\hline Variable & Composite Reliability & Cornbach's Alpha & Description \\
\hline Workload & 0.782 & 0.824 & Reliable \\
\hline Demographic Factor & 0.795 & 0.786 & Reliable \\
\hline Locus Of Control & 0.856 & 0.737 & Reliable \\
\hline Self Esteem & 0.744 & 0.811 & Reliable \\
\hline Workstress & 0.820 & 0.729 & Reliable \\
\hline Burnout & 0.811 & 0.701 & Reliable \\
\hline
\end{tabular}

Source : Output PLS

Based on the table above, the results of composite reliability and Cronbach's alpha test results show a satisfactory value, because all latent variables have a reliable composite value and Cronbach's alpha $\geq 0.70$. This states that all latent variables are said to be Reliable.

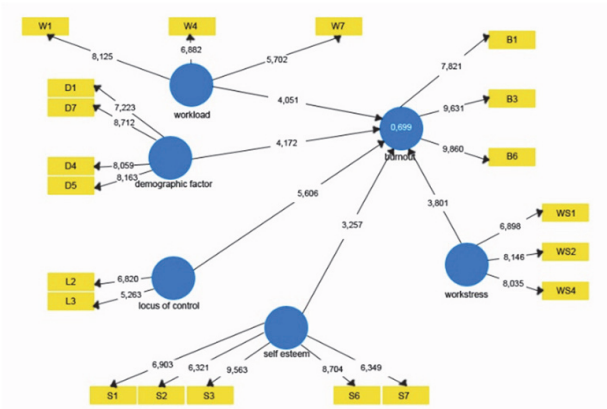

Fig. 2. The Correlation of Variables Source: From data processing (2019)

\subsection{Hypothesis Test}

Table 3 summarizes the results of our survey. 
Table 3

Result of Hypothesis Testing

\begin{tabular}{llllll}
\hline & Original Sample & Standard Deviation & T Statistics & P Values & Conclusion \\
\hline Workload $\rightarrow$ Burnout & 0.319 & 0.288 & 4.051 & 0.001 & Positive- Significant \\
Demographic Factor $\rightarrow$ Burnout & 0.364 & 0.232 & 4.172 & 0.001 & Positive - Significant \\
Locus Of Control $\rightarrow$ Burnout & 0.472 & 0.168 & 5.606 & 0 \\
Self Esteem $\rightarrow$ Burnout & -0.237 & 0.268 & 3.257 & 0.001 & Positive - Significant \\
Workstress $\rightarrow$ Burnout & 0.291 & 0.31 & 3.801 & 0 \\
\hline Source $:$ Output PLS & & & &
\end{tabular}

Source : Output PLS

\section{Conclusion}

Based on the results of this survey, we can make the following conclusions,

\section{Effect of Workload on Burnout}

Based on the hypothesis test in this study the results obtained a T-statistic value of $4.051>1.96$ (Sig. $=0.001$ ) and the result indicates that the workload had a positive and significant effect on burnout. Other research also shows that there is a significant positive relationship between Workload and Burnout PT Train Indonesia Commuter Train Crew Manggarai as supported by the statements of (Soelton et al., 2020; Soelton et al., 2019; Yu, 2014), where the workload had a positive and significant effect against Burnout. This means that if the workload at a company is high, it will cause Burnout. So from the statements of some of these experts the authors can conclude that the Workload is a task given to an employee or group and must be completed within the desired time of the company or employer.

\section{Effect of Demographic Factor on Burnout}

Based on the hypothesis test in this study, the T-statistic value was 4.172>1.96 (Sig. $=0.00)$, and the results indicate that the Demographic Factor had positive and significant effects on burnout. Other studies also show that there was a significant positive relationship between Demographic Factor and Burnout (Saratian et al., 2019, 2020). From the expert's explanation, the writer can conclude that the demographic factor is someone's difference regarding the results of his work based on the background of the person's descendants where each result will be different.

\section{Effect Locus of Control on Burnout}

Based on the hypothesis test in this study, the T-statistic value was 5.606 $>1.96(\mathrm{Sig} .=0.00)$, and the result indicates that the Locus of Control had a positive and significant effect on Burnout. Other research also shows that there is a significant positive relationship between Locus of Control and Burnout PT Indonesia Commuter Train UPT Crew Manggarai KA as supported by Soelton et al., 2019, 2020). This means that if the employee's confidence in a company is good, then it reduces the worries of working. So from the statements of some of these experts, the authors can conclude that the Locus of control is a person's beliefs about what happens to them related to things in themselves such as work success or setbacks or fatigue in a career in control of themselves and can be influenced also by external factors or the influence of others.

\section{Effect of Self Esteem on Burnout}

Based on the hypothesis test in this study, the T-statistic value was $3.257>1.96(\mathrm{Sig} .=0.00)$, and the value shows a negative value, which indicates that Self Esteem had a negative and significant effect on Burnout. Other research also shows that there is a significant negative relationship between Self Esteem and Burnout PT Train Commuter Indonesia UPT Crew Manggarai KA as supported (Soelton et al., 2020), where Self Esteem has a negative and significant effect on Burnout. This means that if the employee's self-esteem in working low, it will lead to worries in the work that will affect the company. From the explanation of some experts about self-esteem, the researcher can conclude that a person's self-esteem can be influenced by 2 (two) factors where the factors are internal and external.

\section{Effect of Workstress on Burnout}

Based on the hypothesis test in this study, the T-statistic value was 3.801 $>1.96$ ( Sig. $=0.00$ ), and the results indicate that Work Stress had a positive and significant effect on Burnout. Other research also shows that there is a significant positive relationship between Work Stress and Burnout PT Train Indonesia Commuter Train Crew Manggarai as supported by statements (Soelton et al., 2020; Yu et al., 2015), where Work Stress has a positive effect and significant towards Burnout. This means that work stress in a company is high, it will make employees who work become lethargic and feel depressed. From some expert statements, it can be concluded by the authors that work stress is a response or reflex from a person to the workload they bear and pressure from other parties which causes fatigue and emotional instability to express one's feelings.

Based on the conclusions above, it can be put forward some Recommendation that is taken into consideration for the company PT. KCI Manggarai Branch and future researchers:

1. Based on the lowest mean workload data "I often get assignments that go past work hours (work past the hours they should)" then from the statement the authors suggest to companies to pay more attention to the service hours of the Masinists s so that they can work by portions that are not through the deadline for work. So that the Masinist can rest sufficiently to maintain health which will later serve again the next day. 
2. Based on the lowest Demographic Factor mean data "Establishing excellent communication between me and coworkers at a young age" from the statement the authors advise companies to maintain good communication between coworkers and leaders at work, so that the company can run smoothly in terms of communication.

3. Based on the lowest Locus of Control mean data "Job promotion is usually good luck" from the statement the authors advise companies to pay attention to the career path aspects received by each employee, so employees can be excited and motivated to work better not based on luck alone. but rather from the results of a machinist's performance.

4. Based on the lowest mean Self Esteem data "My colleague has a positive influence on my work environment" is positive but the results are negative than from the statement the authors suggest that the company is expected to motivate machinists so that they can give positive influence between fellow employees enhance cooperation between machinists.

5. Based on the data of the lowest mean Work Stress "I feel the equipment in the company is inadequate" from the statement the authors suggest that the company can pay more attention to the equipment used by machinists so that it is in normal condition and can function as it should when certain conditions.

6. Based on the data of the lowest mean Work Stress "Because of the many jobs, I feel depressed" from the statement the authors suggest that companies pay more attention to the mental condition of each employee is machined so that the work received is under its portion and the machinists can work with focus and comfort.

The researcher suggests that further research adds other variables considering that Endogen Burnout variables in this study can only be explained by exogenous variables of $80.2 \%$ (0.802) namely Workload, Demographic Factor, Locus of Control, Self Esteem and Work Stress. It is expected that by adding other exogenous variables such as Work-Family Conflict and Work-Life Balance, the coefficient of determination on the Burnout variable can increase.

\section{References}

Abdelhamied, H. H. S. (2018). The Effects of Work Characteristics and Self-esteem on Work Burnout for Supervisory-levels Employees in Hotels. Journal of Tourism and Hospitality Management, 6(1), 9-24.

Bitsadze, M., \& Japaridze, M. (2016). Locus of control in Georgian teachers and its relation to teacher burnout. Problems of Management in the 21st Century, 11(1), 8-15.

Coopersmith, S. (1967). The antecedents of self-esteem San Francisco. H Freeman and Company.

Dessler, G. (2013). Manajemen Sumber Daya Manusia Human Reources, Jilid 2. Prenhalindo, Jakarta.

Dyrbye, L. N., \& Shanafelt, T. D. (2011). Physician burnout: a potential threat to successful health care reform. Jama, 305(19), $2009-2010$.

Robbins, S. P., \& Judge, T. A. (2014). Essentials of organizational behavior .[DX Kindle version].

Shafiezadeh, K. R. (2011). The prevalence of musculoskeletal disorders and its relationship to general health statement in hospital. Nurse Life Science Journal, 8(4), 1-6.

Soelton, M., Amalia, D., Noermijati, N., \& Wahyudiono, B. (2020, February). Self-esteem: the levels of religiosity in job insecurity and stress in government company. In 4th International Conference on Management, Economics and Business (ICMEB 2019) (pp. 302310). Atlantis Press.

Soelton, M., Hardianti, D., Kuncoro, S., \& Soelton, J. (2020, February). Factors affecting burnout in manufacturing industries. In 4th International Conference on Management, Economics and Business (ICMEB 2019) (pp. 46-52). Atlantis Press.

Soelton, M., Lestari, P. A., Arief, H., \& Putra, R. L. (2020, February). The effect of role conflict and burnout toward turnover intention at software industries, work stress as moderating variables. In 4th International Conference on Management, Economics and Business (ICMEB 2019) (pp. 185-190). Atlantis Press.

Soelton, M. (2018). Toward the best model in recruitment process and employee competence in outsourcing industries. Jurnal Ekonomi, 23(2), 240-250

Soelton, M., \& Yasinta, D. (2018). Pengaruh kepemimpinan transformasional, lingkungan kerja fisik dan stres kerja terhadap kinerja pegawai pada kantor kecamatan penjaringan jakarta utara. Jurnal Ekonomi, 23(1), 20-32.

Soelton, M., Nugrahati, T., Setiawan, M., Rohman, F., \& Pratama, A. (2019). Gender: Stress levels on performance in modern Industry. Archives of Business Research, 7(2).

Soelton, M., \& Umar, M. (2018). Recognizing how the time demands of work influences the turn over intention in banking Industry. European Journal of Business and Management (EJBM), 12, 19.

Soelton, M., Noermijati, N., Rohman, F., Mugiono, M., Aulia, I., \& Siregar, R. (2020). Reawakening perceived person organization fit and perceived person job fit: Removing obstacles organizational commitment. Management Science Letters, 10(13), $2993-3002$.

Suwarsi, S., \& Budianti, N. (2009). Influence of locus of control and job involvement to organizational culture applied by employees on bank X. World Academy of Science, Engineering and Technology, 60, 616-621.

Tarwaka. (2015). Industrial Ergonomics: Fundamentals of Ergonomic Knowledge and Application in the Workplace. Harapan Press: Solo

Xiaoming, Y., Ma, B. J., Chang, C. L., \& Shieh, C. J. (2014). Effects of workload on burnout and turnover intention of medical staff: A study. Studies on ethno-medicine, 8(3), 229-237.

Yu, X., Wang, P., Zhai, X., Dai, H., \& Yang, Q. (2015). The effect of work stress on job burnout among teachers: The mediating role of self-efficacy. Social Indicators Research, 122(3), 701-708.

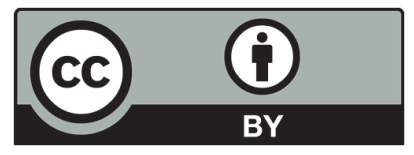

(C) 2020 by the authors; licensee Growing Science, Canada. This is an open access article distributed under the terms and conditions of the Creative Commons Attribution (CC-BY) license (http://creativecommons.org/licenses/by/4.0/). 